\title{
Virulence Factors of Clostridium difficile and Its Pathogenesis in Intestinal Infection in Man
}

\author{
Shigeru KamiYa ${ }^{1 *}$ and Shinichi Nakamura ${ }^{2}$ \\ 1*Department of Infectious Diseases, Division of Host Defense Mechanism, School of Medicine, \\ Tokai University, Isehara 259-11 and \\ ${ }^{2}$ Department of Bacteriology, School of Medicine, Kanazawa University, Kanazawa 920
}

(Received for publication, October 5,1992 )

Key words: Clostridium difficile; virulence factor; toxin; pseudomembranous colitis (PMC); antimicrobial agent-associated diarrhoea (AAD)

Clostridium difficile was isolated in 1935 by Hall and O'Toole (29) from the feces of healthy neonate, and the microorganism was first designated Bacillus difficilis. The 'difficilis' was originated from the difficulty in cultivation of the microorganism. They showed that the microorganism had lethality to rabbit or guinea pig and edema-inducing activity. Later the microorganism was classified as Clostridium difficile in 1938 by Prévot (71). The pathogenicity of $C$. difficile to human had not been reported until when association of $C$. difficile with human pseudomembranous colitis (PMC) was demonstrated in 1978.

In 1893, Finney (19) first reported an occurrence of PMC in the patient with peptic ulcer after gastroenterostomy. The number of cases with PMC increased in parallel to an increase of use of antibiotics in the 1970s. Although Staphylococcus aureus was speculated to be a causative agent for PMC, there was no determinative evidence for the hypothesis. In 1977, Larson et al (48) reported that clostridial toxin was causative agent for PMC, and in 1978 toxigenic $C$. difficile was identified as a cause of PMC by Bartlett et al (3), George et al (23) and Larson et al (49). The isolation rate of $C$. difficile from feces of healthy adults was $0-12.8 \%$, and that of the patients with PMC was $80-100 \%$ (59). It is considered that change of intestinal flora by administration of antimicrobial agent and following selection of toxin-producing $C$. difficile are background for the occurrence of PMC. Virulence factors of $C$. difficile and its pathogenesis in intestinal infection in man are discussed in this review by indicating not only previous reports in the literature but also our own experimental data.

\section{VIRULENCE FACTORS OF C. DIFFICILE}

Virulence factors of $C$. difficile reported so far are listed in Table 1. Toxins 
Table 1. Virulence factors of Clostridium difficile

\begin{tabular}{|c|c|c|}
\hline Virulence factor & Action & Reference \\
\hline Toxins & & $1,46,53,77$ \\
\hline Toxin A (enterotoxin) & $\begin{array}{l}\text { Enterotoxicity, cytotoxicity, } \\
\text { mouse lethality }\end{array}$ & \\
\hline Toxin B (cytotoxin) & Cytotoxicity, mouse lethality & \\
\hline Mucosal association & Adherence to mucosa & 6 \\
\hline Fimbriae & Adherence to mucosa & 5 \\
\hline Capsule & Anti-phagocytosis & 11,76 \\
\hline $\begin{array}{l}\text { Tissue degradative enzymes } \\
\text { hyaluronidase } \\
\text { chondroitin-4-sulfatase } \\
\text { collagenase }\end{array}$ & $\begin{array}{l}\text { Hydrolysis of mucus and } \\
\text { destruction of intestinal } \\
\text { cells }\end{array}$ & 75 \\
\hline
\end{tabular}

produced by $C$. difficile are considered to be the most important virulence factor. It is known that $C$. difficile produces two toxins: toxin A (enterotoxin) and toxin B (cytotoxin) $(1,77)$. Toxin $\mathrm{A}$ has an enterotoxicity inducing fluid accumulation in ileal loop response test. Toxin B has a strong cytotoxicity to cultured cells. Nakamura et al (65) found that strains with a particular serotype (serovar) are found in isolates from patients and are highly toxigenic, suggesting that surface characteristics of the bacteria are related with the pathogenesis. By animal experiments using hamsters administrated with clindamycin prior to $C$. difficile infection, Borriello et al $(6)$ reported that $C$. difficile strains were classified into highly virulent strain causing death within two days after the inoculation, less virulent strain causing death between 3 and 14 days after the inoculation, and avirulent strain causing no death. In vitro toxin A production and association with intestinal mucosa were detected much more in highly virulent strains of $C$. difficile than in less virulent strains. On the other hand, there was no significant difference in in vitro toxin production between highly virulent and less virulent strains. They speculated that pathogenicity of $C$. difficile was determined by the intensity of association of the microorganism with intestinal epithelial cells. Fimbriae and capsule were reported as candidates for mucosal association factors $(5,11,76)$. Their roles in adhesion, however, are not clear. As other factors associated with pathogenesis of $C$. difficile, tissue-degradative enzymes, hyaluronidase, chondroitin-4-sulfatase and collagenase, were reported (75). Further investigation on the tissue-degradative enzymes of C. difficile is needed.

\section{DIFFICILE TOXINS}

Some characteristics of toxins produced by $C$. difficile are listed in Table 2 . Toxins A and B are eluted on anion-exchange column (Mono Q column) at 0.3$0.4 \mathrm{~m}$ and $0.6-0.7 \mathrm{M} \mathrm{NaCl}$, respectively. Toxin $\mathrm{A}$ has an enterotoxicity which induces fluid accumulation with hemorrhage in ileal loop response test. In contrast, toxin B which induces strong cytotoxicity to cultured cells has no enterotoxicity 
Table 2. Characteristics of Clostridium difficile toxins $(37,46,53,59,77)$

\begin{tabular}{|c|c|c|}
\hline Characteristics & Toxin A & Toxin B \\
\hline Enterotoxicity & + & - \\
\hline Cytotoxicity & + & W \\
\hline Mouse lethality & + & + \\
\hline \multicolumn{3}{|c|}{$\begin{array}{l}\text { Hemagglutination (HA) activity } \\
\text { with rabbit erythrocytes }\end{array}$} \\
\hline $4^{\circ} \mathrm{C}$ & + & - \\
\hline $37^{\circ} \mathrm{C}$ & - & - \\
\hline \multicolumn{3}{|c|}{ Binding to hamster brush border membrane } \\
\hline $4^{\circ} \mathrm{C}$ & W & N.T.a) \\
\hline $37^{\circ} \mathrm{C}$ & + & N.T. \\
\hline \multicolumn{3}{|c|}{ Binding to bovine thyroglobulin } \\
\hline $4^{\circ} \mathrm{C}$ & + & - \\
\hline $37^{\circ} \mathrm{C}$ & - & - \\
\hline \multicolumn{3}{|l|}{ Molecular weight } \\
\hline non-denatured condition & $400-600 \mathrm{kDa}$ & $300-400 \mathrm{kDa}$ \\
\hline denatured condition & $200-300 \mathrm{kDa}$ & $200-300 \mathrm{kDa}$ \\
\hline
\end{tabular}

a) Not tested.

at all. The cytotoxicity of toxin B is much stronger by $100-1000$ fold than that of toxin A. Both toxins have mouse lethality. Krivan et al (46) reported that toxin A binds temperature-dependently to hamster intestinal brush border membrane, rabbit erythrocytes and bovine thyroglobulin. Toxin $\mathrm{B}$ has not such binding activity. Krivan and Wilkins (47) reported a new purification procedure, thyroglobulin affinity chromatography (TGAC), for toxin A by taking advantage of temperature-dependent binding activity of the toxin to bovine thyroglobulin (binding at $4^{\circ} \mathrm{C}$ and releasing at $37^{\circ} \mathrm{C}$ ). We have modified the purification procedure by applying the TGAC-thermal eluents into anion-exchange chromatography $(Q$ Sepharose FF and Mono Q) (Fig. 1) (37). The highly purified toxin A was analyzed by polyacrylamide gel electrophoresis (PAGE) stained by silver. By native- and SDS-PAGE analysis, it was demonstrated that the molecular weight (MW) of toxin $\mathrm{A}$ in non-denatured and denatured conditions were $540 \mathrm{kDa}$ and $240 \mathrm{kDa}$, respectively (Fig. 2). In SDS-PAGE, many minor bands ranging from 38 to 440 $\mathrm{kDa}$ were also detected by silver stain (Fig. 2B). Lyerly et al (53) also reported a similar result in SDS-PAGE of toxin A, implying a possibility that toxin $\mathrm{A}$ is an aggregate of smaller subunits. The MW of toxin B is reported to be $300-400 \mathrm{kDa}$ and $200-300 \mathrm{kDa}$ in non-denatured and denatured conditions, respectively $(1,53$, 77). Recently, DNA cloning of toxin gene has been performed and base sequence of the gene has been determined. The MW of toxins A and B were estimated to be $308 \mathrm{kDa}(13)$ and $270 \mathrm{kDa}(2)$, respectively.

As trisaccharide sequence, Gal $\alpha 1-3 \mathrm{Gal} \beta 1-4 \mathrm{GlcNAc}$, is commonly detected on the surfaces of hamster brush border membrane, rabbit erythrocyte and bovine thyroglobulin to which toxin A binds temperature-dependently, the sequence was speculated to be a receptor for toxin A (46). However, it was reported that the 


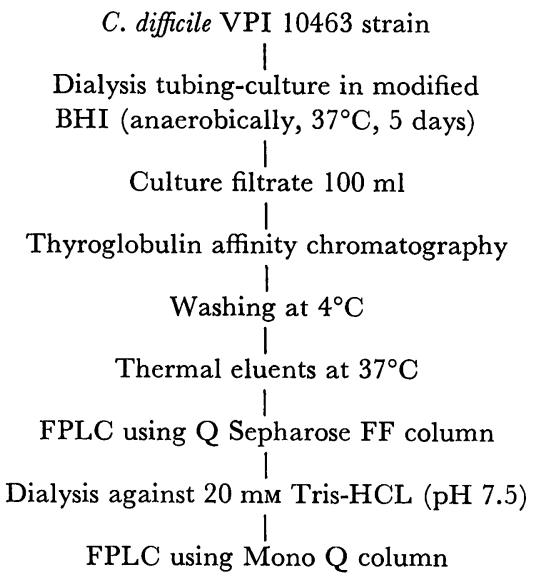

Fig. 1. Purification of toxin A by thyroglobulin affinity chromatography followed by anion-exchange chromatography.

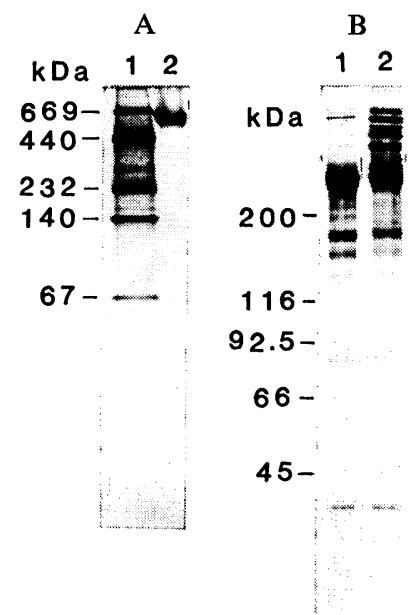

Fig. 2. Polyacrylamide gel electrophoresis (PAGE) analysis of purified toxin A. (A) Native PAGE stained by silver: 1, molecular weight standards; 2 , purified toxin A $(5 \mu \mathrm{g})$. (B) SDS-PAGE stained by silver: 1 , toxin A $(5 \mu \mathrm{g})$ in reduced condition by $\beta$ mercaptoethanol; 2, toxin A (5 $\mu \mathrm{g})$ in non-reduced condition.

trisaccharide is not detected on the surface of human intestinal epithelial cells (21). Recently, it was shown that a receptor for toxin A might be disaccharide of Gal $\beta 1$ 4GlcNAc detectable on the surface of human intestinal cell $(80)$. We have shown that the peaks of hemagglutination (HA) activity and cytotoxicity of toxin A were dissociated by direct analysis of culture filtrate of $C$. difficile VPI 10463 strain in Mono Q-FPLC (fast protein liquid chromatography), suggesting a presence of nonhemagglutinating form (toxin $\mathrm{A}^{\prime}$ ) of toxin $\mathrm{A}$. Toxin $\mathrm{A}^{\prime}$ was purified using TGAC- 
Table 3. Purification of non-hemagglutinating form (toxin $\mathrm{A}^{\prime}$ ) of toxin $\mathrm{A}$ by Mono $Q$ anion-exchange chromatography (33)

\begin{tabular}{|c|c|c|c|c|c|}
\hline \multirow{2}{*}{$\begin{array}{c}\text { Fraction } \\
\text { No. }\end{array}$} & \multirow{2}{*}{$\begin{array}{l}\text { Conc. of } \\
\mathrm{NaCl}(\mathrm{M})\end{array}$} & \multicolumn{2}{|c|}{ Toxin $\mathrm{A}^{a)}$} & \multicolumn{2}{|c|}{ Toxin $\left.\mathrm{A}^{\prime} a\right)$} \\
\hline & & Cytotoxicity ${ }^{b)}$ & $\mathrm{HA}_{\text {activity }}{ }^{()}$ & Cytotoxicity & HA activity \\
\hline 37 & 0.29 & $<3$ & $<1$ & 6 & $<1$ \\
\hline 38 & 0.30 & 11 & 2 & 13 & $<1$ \\
\hline 39 & 0.31 & 13 & 5 & 14 & $<1$ \\
\hline 40 & 0.32 & 12 & 6 & 13 & 1 \\
\hline 41 & 0.33 & 10 & 4 & 13 & 1 \\
\hline 42 & 0.34 & 8 & 2 & 11 & $<1$ \\
\hline 43 & 0.35 & 6 & $<1$ & 10 & $<1$ \\
\hline \multicolumn{6}{|c|}{$\begin{array}{l}\text { a) After thyroglobulin affinity chromatography (TGAC) of } C \text {. difficile culture filtrate, } \\
\text { TGAC-thermal eluents and TGAC-unbound fractions were applied into } Q \text { Sepharose FF } \\
\text { and Mono } Q \text { anion-exchange chromatography for purification of toxin } A \text { and toxin } A^{\prime} \text {, } \\
\text { respectively. } \\
\text { b) } \log _{2} \mathrm{CU} / 50 \mu \mathrm{l} \text {. } \\
\text { c) } \log _{2} \mathrm{HAU} / 50 \mu \mathrm{l} \text {. }\end{array}$} \\
\hline
\end{tabular}

Table 4. Biological activity of toxin $\mathrm{A}$ and toxin $\mathrm{A}^{\prime}(33,34)$

\begin{tabular}{|c|c|c|c|c|}
\hline \multirow[b]{2}{*}{ Toxin } & \multicolumn{3}{|c|}{ Minimum dose (ng) causing each activity } & \multirow[b]{2}{*}{ Loop test $\left.{ }^{a}\right)$} \\
\hline & Cytotoxicity & Mouse lethality & HA activity & \\
\hline Toxin A & 0.14 & 18 & 70 & $+(1.58)^{b)}$ \\
\hline Toxin $\mathrm{A}^{\prime}$ & 0.14 & 4.4 & $>8800$ & $+(1.63)$ \\
\hline
\end{tabular}

unbound fractions of culture filtrate by Q Sepharose FF- and Mono Q-FPLC (Table 3) (33). Toxin $\mathrm{A}^{\prime}$ was demonstrated to have the same MWs (540 kDa in non-denatured and $240 \mathrm{kDa}$ in denatured conditions) as those of toxin $\mathrm{A}$, suggesting that toxin $\mathrm{A}^{\prime}$ might be conformationally different from toxin $\mathrm{A}$. Interestingly, toxin $\mathrm{A}^{\prime}$ without $\mathrm{HA}$ activity has as much enterotoxicity as toxin $\mathrm{A}$ with $\mathrm{HA}$ activity (Table 4), implying a possibility that HA activity might be not necessary for induction of enteropathogenicity of toxin A (34).

Among many monoclonal antibodies (MAb) to $C$. difficile toxin A raised so far $(14,53,73)$, PCG-4 produced by Lyerly et al (53) was the only MAb to neutralize biological activity of toxin A. The MAb, PCG-4, neutralized both enterotoxicity and HA activity of toxin A, implying the presence of common epitope for enterotoxicity and HA activity. We have established 9 MAbs to $C$. difficile toxin A using highly purified toxin A for immunization of mice (38). Immunoblot analysis using 37B5, one of the 9 MAbs, showed that toxin $\mathrm{A}^{\prime}$ reacted with the MAb as effectively as toxin A did (Fig. 3). It was also shown that 37B5 neutralized enterotoxicity of 
A B

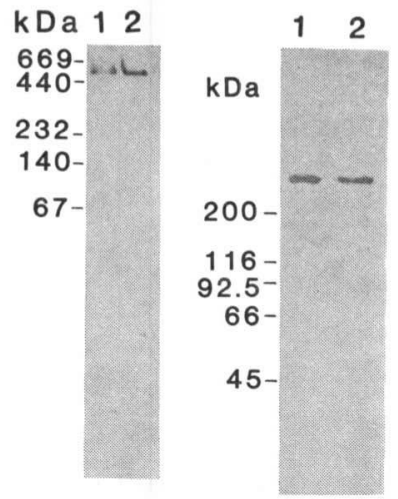

Fig. 3. Immunoblot analysis of toxin $\mathrm{A}$ and toxin $\mathrm{A}^{\prime}$ by using monoclonal antibody (37B5) to toxin A. (A) Immunoblot analysis after native PAGE of toxin A $(5 \mu \mathrm{g})$ (lane 1) and toxin $\mathrm{A}^{\prime}(5 \mu \mathrm{g})$ (lane 2). (B) Immunoblot analysis after SDS-PAGE of toxin A $(5 \mu \mathrm{g})$ (lane 1) and toxin $\mathrm{A}^{\prime}(5 \mu \mathrm{g})$ (lane 2).

toxin $\mathrm{A}$, but not HA activity, sustaining the hypothesis that HA activity of toxin A is not necessary for induction of enterotoxicity.

Giuliano et al (28) reported the existence of the third toxin (toxin C) of $C$. difficile, which induces enterotoxicity without hemorrhage in ileal loop response test. The toxin was eluted near toxin B fractions in Mono Q-FPLC. However, due to a fragile characteristics of the toxin, further analysis has not been performed.

Although the mechanism of occurrence of diarrhea by $C$. difficile toxins has not been fully understood, pathogenic effect of toxins on intestinal cells is assumed as described below $(20,30,59,70)$. Toxin A binds to intestinal epithelial cells and is internalized into the cell. Consequently, infiltration of granulocytes into lamina propria of intestinal mucosa is followed by release of various chemical transmitters. Cytotoxic change of intestinal cells results in increased permeability inducing fluid secretion into intestinal lumen. By co-operation of cytotoxic effect of toxin $\mathrm{A}$ on intestinal cells, toxin B can enter the intestinal cell and exert its strong cytopathogenicity.

Both toxins induce a change of microfilament system which is composed of dissociation of actin filament and intracellular accumulation of globular actin (69, 79). This seems to be a cause of the cytotoxicity of cultured cells by $C$. difficile toxins. It was reported that both toxins did not inhibit phagocytic activity of neutrophils (9). On the other hand, Däubener et al (10) showed that both toxins inhibited monocyte-dependent $\mathrm{T}$ cell proliferation. Toxin $\mathrm{A}$ has been reported to have promotive effect on proliferation of spleen cells in the presence of calcium ionophore (58) and enhancing activity of cell-mediated cytotoxicity by peripheral mononuclear cells $(56)$. A detailed relationship between $C$. difficile toxins and immune system should be determined in the future. 
Table 5. Antimicrobial susceptibility of Clostridium difficile strains (64)

\begin{tabular}{|c|c|c|c|c|c|c|c|c|c|}
\hline \multirow{2}{*}{ Antimicrobial agent } & \multicolumn{9}{|c|}{ Number of strains showing MIC $(\mu \mathrm{g} / \mathrm{ml})$ of } \\
\hline & $\leqq 0.39$ & 0.78 & 1.56 & 3.13 & 6.25 & 12.5 & 25 & 50 & $\geqq 100$ \\
\hline Rifampicin & 78 & 1 & & & & & & & \\
\hline Metronidazole & 79 & & & & & & & & \\
\hline Fusidic acid & 70 & 9 & & & & & & & \\
\hline Vancomycin & & 10 & 69 & & & & & & \\
\hline Penicillin G & & 59 & 9 & 6 & 5 & & & & \\
\hline Ampicillin & & 28 & 37 & 9 & 5 & & & & \\
\hline Cephalothin & & 1 & 36 & 25 & 13 & 4 & & & \\
\hline Cephaloridine & & 1 & 8 & 32 & 31 & 7 & & & \\
\hline Carbenicillin & & & & & 48 & 14 & 14 & 3 & \\
\hline Neomycin & & & & & & & 1 & 12 & 66 \\
\hline Gentamicin & & & & & & & & 4 & 75 \\
\hline Cefoxitin & & & & & & & & 3 & 76 \\
\hline $\begin{array}{l}\text { Cefalexin, sulfamethoxazole, } \\
\text { trimethoprim, kanamycin, } \\
\text { streptomycin, nalidixic acid, } \\
\text { cycloserine }\end{array}$ & & & & & & & & & 79 \\
\hline Erythromycin & 29 & 13 & & & & & & & 37 \\
\hline Clindamycin & & 3 & 8 & 30 & 1 & & & & 37 \\
\hline Lincomycin & & & 2 & 12 & 17 & 10 & 1 & & 37 \\
\hline Chloramphenicol & & & 46 & 10 & 9 & & & 14 & \\
\hline Tetracycline & 11 & 40 & 8 & 1 & & & & 19 & \\
\hline
\end{tabular}

\section{ANTIMICROBIAL SUSCEPTIBILITY OF C. DIFFICILE AND INCREASED TOXIN PRODUCTION OF C. DIFFICILE BY ANTIMICROBIAL AGENTS}

It is known that $C$. difficile is more resistant against various antimicrobial agents than any other clostridia $(18,27,64,67)$. Our experimental data on antimicrobial susceptibility of $C$. difficile are shown in Table 5. C. difficile is highly resistant against aminoglycosides, trimethoprim, sulfamethoxazole, nalidixic acid, cycloserine, neomycin, cefoxitin and cephalexin. On the other hand, $C$. difficile has sensitivity to rifampicin, metronidazole, fusidic acid, vancomycin, ampicillin and penicillin $\mathrm{G}$. With respect to susceptibility to erythromycin, clindamycin, lincomycin, chloramphenicol and tetracycline, $C$. difficile strains are divided into two groups, resistant and sensitive strains to these agents. The fact that $C$. difficile has high resistance against many antimicrobial agents seems to be closely related with selective proliferation of $C$. difficile in the patients with PMC or AAD after administration of antimicrobial agents.

It has been reported that toxin production of $C$. difficile is increased in the presence of various antimicrobial agents, particularly clindamycin (22). In contrast, when $C$. difficile was incubated in continuous flow culture, toxin production was enhanced by addition of vancomycin or penicillin, but not clindamycin (68). Nakamura et al (62) examined the effect of clindamycin on cytotoxin (toxin B) production using $80 \mathrm{C}$. difficile strains (56 toxigenic and 24 nontoxigenic). It was 
noted that cytotoxin production was markedly increased in 6 toxigenic strains. Toxin A production was also reported to be increased in the presence of clinda$\operatorname{mycin}(31)$.

\section{SPORULATION OF C. DIFFICILE}

C. difficile spores can survive for longer than 5 months under atmosphere (44). It is difficult to recover $C$. difficile spores by ordinary growth medium like brain heart infusion (BHI). The recovery rate of most strains was lower than $0.01 \%$ in BHI medium. However, the recovery is distinctly enhanced when either the spores are treated with $0.5 \mathrm{~m}$ sodium thioglycolate at $50^{\circ} \mathrm{C}$ for $30 \mathrm{~min}$ and inoculated in lysozyme $(10 \mu \mathrm{g} / \mathrm{ml})$-containing medium (thioglycolate-lysozyme method) $(32,66)$, or a medium supplemented with sodium taurocholate $(0.1 \%)$ is used for spore recovery medium (taurocholate method) (83). The mean value of recovery rates of 103 C. difficile strains in the taurocholate method $(89 \%)$ was significantly higher than that in thioglycolate-lysozyme method $(64 \%)(39)$. The determinative conditions of heating or alkali treatment that alter C. diffcile spores were $80^{\circ} \mathrm{C}$ for $10 \mathrm{~min}$ or $0.1 \mathrm{~N} \mathrm{NaOH}$ for $15 \mathrm{~min}$, respectively (40). For recovery of such altered spores, thioglycolate-lysozyme method was much more effective than taurocholate method (Table 6) (40). It was reported that toxin production was detected after the exponential growth phase, and maximum yield was found in culture filtrate at 4-5 days after inoculation when bacterial growth was already arrested $(42,50)$, suggesting

Table 6. Recovery of spores of $C$. difficile altered by heat or alkali $(39,40)$

\begin{tabular}{|c|c|c|c|}
\hline \multirow{2}{*}{ Treatment } & \multirow{2}{*}{ Strain } & \multicolumn{2}{|c|}{ Relative recovery rate $a)(\%)$} \\
\hline & & Taurocholate method & $\begin{array}{l}\text { Thioglycolate-lysozyme } \\
\text { method }\end{array}$ \\
\hline \multirow[t]{4}{*}{$80^{\circ} \mathrm{C}, 10 \mathrm{~min}$} & $\mathrm{KZ} 1628$ & 2.9 & 80 \\
\hline & KZ 1648 & 2.1 & 41 \\
\hline & $\mathrm{KZ} 1610$ & 0.73 & 58 \\
\hline & $\mathrm{KZ} 1660$ & 0.050 & 28 \\
\hline \multirow[t]{4}{*}{$90^{\circ} \mathrm{C}, 10 \mathrm{~min}$} & $\mathrm{KZ} 1628$ & $<0.00001$ & 33 \\
\hline & $\mathrm{KZ} 1648$ & $<0.00001$ & 10 \\
\hline & $\mathrm{KZ} 1610$ & $<0.00001$ & 18 \\
\hline & $\mathrm{KZ} 1660$ & $<0.00001$ & 17 \\
\hline $0.1 \mathrm{~N} \mathrm{NaOH}$ & $\mathrm{KZ} 1628$ & 91 & 32 \\
\hline \multirow[t]{3}{*}{$15 \min$} & $\mathrm{KZ} 1648$ & 60 & 46 \\
\hline & $\mathrm{KZ} 1610$ & 1.3 & 50 \\
\hline & KZ 1660 & 5.9 & 34 \\
\hline $0.2 \mathrm{~N} \mathrm{NaOH}$ & KZ 1628 & 0.074 & 41 \\
\hline \multirow[t]{3}{*}{$15 \mathrm{~min}$} & $\mathrm{KZ} 1648$ & 0.049 & 40 \\
\hline & $\mathrm{KZ} 1610$ & 0.0034 & 48 \\
\hline & KZ 1660 & 0.017 & 34 \\
\hline
\end{tabular}

a) Ratio of the number of recovered spores after various treatments to that of spores heated at $70^{\circ} \mathrm{C}$ for $10 \mathrm{~min}$ recovered by taurocholate methods. 
Table 7. Relationship between sporulation and cytotoxin production of Clostridium difficile $\mathrm{KZ} 1630$ strain (36)

\begin{tabular}{|c|c|c|c|c|c|c|}
\hline \multirow{2}{*}{$\begin{array}{c}\text { Time (hr) } \\
\text { after } \\
\text { inoculation }\end{array}$} & \multicolumn{3}{|c|}{ Untreated } & \multicolumn{3}{|c|}{ Acridine orange-treated $\left.{ }^{b}\right)$} \\
\hline & $\begin{array}{l}\text { Vegetative } \\
\text { cells } s^{c)}\end{array}$ & Spores $^{c)}$ & $\begin{array}{c}\text { Cyto- } \\
\text { toxicity }\end{array}$ & $\begin{array}{l}\text { Vegetative } \\
\text { cells }\end{array}$ & Spores & Cytotoxicity \\
\hline 12 & 7.3 & $\mathrm{ND}^{e)}$ & ND & 7.6 & ND & ND \\
\hline 24 & 8.1 & 3.2 & 6 & 8.1 & ND & 2 \\
\hline 36 & 7.9 & 5.9 & 10 & 8.2 & 1.2 & 3 \\
\hline 48 & 7.9 & 6.8 & 12 & 8.2 & 2.0 & 5 \\
\hline 60 & 7.9 & 7.1 & 12 & 8.0 & 3.9 & 7 \\
\hline 72 & 7.5 & 7.0 & 12 & 7.8 & 4.1 & 7 \\
\hline
\end{tabular}

a) Three-tenth $\mathrm{ml}$ of $10^{6}$-diluted culture of the strain incubated at $37^{\circ} \mathrm{C}$ for $5-6 \mathrm{hr}$ was inoculated into $15 \mathrm{ml} \mathrm{m}$-BHI medium.

b) Acridine orange $(30 \mu \mathrm{g} / \mathrm{ml})$ was added $12 \mathrm{hr}$ after the inoculation.

c) $\log _{10} \mathrm{CFU} / \mathrm{ml}$.

d) Extracellular cytotoxicity $\left(\log _{2} \mathrm{CU} / 50 \mu \mathrm{l}\right)$.

e) Not detected.

a relationship between toxin production and sporulation of $C$. difficile. However, Onderdonk et al (68) showed no correlation between cytotoxin production and sporulation in studies with a continuous flow culture system. Ketley et al (43) also reported that the kinetics of spore production by $C$. difficile were not paralleled by release of toxin $\mathrm{A}$ in vitro and that toxin $\mathrm{A}$ was not found to be associated with either purified whole spores or spore coats. In their experiments, however, considerable large number of spores in the inoculum was applied, which made the analysis on the relationship between sporulation and toxin production more difficult. In contrast, by inoculating of $10^{6}$-diluted $\mathrm{KZ} 1630$ culture which had been incubated anaerobically for 5-6 hr to give an initial count of less than 10 vegetative cells $/ \mathrm{ml}$ with no spores, the relationship between cytotoxin production and sporulation was reinvestigated (36). Cytotoxin production was coincidental to the phase of spore formation of $C$. difficile (Table 7). It was also shown that addition of a sporulation inhibitor, acridine orange $(30 \mu \mathrm{g} / \mathrm{ml})$, decreased significantly both sporulation and cytotoxin production in spite of no effect on the growth of vegetative cells (Table 7). These results suggest closer relationship between sporulation and cytotoxin production.

\section{INTESTINAL INFECTION BY C. DIFFICILE}

C. difficile is a causative microorganism of PMC and some cases $(20 \%)$ of AAD (24). PMC is a severe inflammatory disease in colon mucosa with formation of pseudomembrane composed of fibrin, mucus, leukocytes and necrotic intestinal epithelium. The more antimicrobial agent was used for patients in the 1970s, the more the number of the cases of PMC increased. Major clinical symptoms are diarrhea, abdominal pain and fever occurring after antimicrobial agent administration. The change of intestinal flora caused by the administration of the drug 
results in selective proliferation of $C$. difficile with production of various virulence factors including toxins $\mathrm{A}$ and $\mathrm{B}$. Athough clindamycin and lincomycin were first considered to be the main causative antimicrobial agents for PMC and AAD, it is now known that all antimicrobial agents except for non-oral administration of aminoglycosides are associated with the occurrence of PMC or AAD. It is considered that antimicrobial agents are closely related with both selective proliferation of $C$. difficile and increased toxin production by $C$. difficile. Isolation rates of $C$. difficile were $0-12.8 \%, 0-50 \%$ and $80-100 \%$ from the feces of healthy adults, patients administrated with antimicrobial agent, and patients with PMC, respectively (25, $59,61,81)$. In contrast, high isolation rate $(30-80 \%)$ was observed in the feces of healthy babies, particularly neonates, and approximately $30 \%$ of the feces showed positive-cytotoxicity (59). Despite that toxigenic $C$. difficile was isolated and high cytotoxicity $\left(10^{2}-10^{6} \mathrm{CU} / 50 \mu \mathrm{l}\right)$ was detected in the fecal extract, no diarrhea was induced in the intestine of neonates. The reason who no symptom of enterocolitis was induced in the babies remains to be determined. Krivan et al (46) supposed that the receptor for $C$. difficile toxins might not be expressed on the surface of naonate intestinal cells. However, Rolfe (72) recently reported that there was no significant difference in the binding activity of toxin A between adult and neonate hamster brush border membranes.

\section{LABORATORY TESTS FOR C. DIFFICILE}

Laboratory tests for C. difficile are listed in Table 8. For isolation of C. difficile, anaerobic incubation using CCFA (cycloserine-cefoxitin-fructose-agar) (26) is performed. As mentioned above, thioglycolate-lysozyme and taurocholate methods are effective for the recovery of $C$. difficile spores. Cytotoxicity assay is a sensitive method for detection of $C$. difficile toxins. Cultured cells treated with $C$. difficile toxins exhibited cytopathic effect of cell rouding with refractile appearance (Fig. 4).

Table 8. Laboratory tests for $C$. difficile $(35,41,54,59,60,63,84)$

\begin{tabular}{|c|c|c|}
\hline Test & Target & Remarks \\
\hline Anaerobic culture & C. difficile & $\begin{array}{l}\text { C. difficile can be isolated } \\
\text { Two to three days are needed } \\
\text { for incubation }\end{array}$ \\
\hline Cytotoxicity assay & C. difficile toxins & $\begin{array}{l}\text { The most sensitive method } \\
\text { (detectable for } 1 \mathrm{pg} \text { of toxin B) } \\
\text { Cultured cells are needed }\end{array}$ \\
\hline $\begin{array}{l}\text { Enzyme-linked immunosorbent } \\
\text { assay (ELISA) }\end{array}$ & C. difficile toxins & $\begin{array}{l}\text { High specificity } \\
\text { Special apparatus is needed } \\
\text { Rapid screening assay }\end{array}$ \\
\hline Latex agglutination assay & $\begin{array}{l}\text { C. difficile antigen (glu- } \\
\text { tamate dehydrogenase) }\end{array}$ & Nonspecific reaction is observed \\
\hline $\begin{array}{l}\text { Polymerase chain } \\
\text { reaction }(\mathrm{PCR})\end{array}$ & Toxin genes & $\begin{array}{l}\text { Detectable for small number of } \\
\text { toxigenic } C \text {. difficile } \\
\text { Existence of inhibitors in fecal } \\
\text { extract }\end{array}$ \\
\hline
\end{tabular}




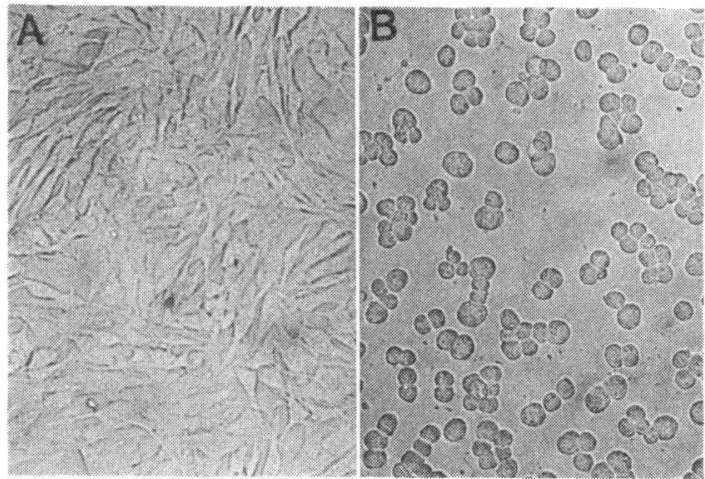

Fig. 4. Cytotoxicity assay for $C$. difficile toxins. (A) Untreated BHK-21/W1-2 (baby hamster kidney) cells. (B) BHK-21/W1-2 cells treated for $24 \mathrm{hr}$ with $C$. difficile culture filtrate containing both toxin $\mathrm{A}$ and toxin $\mathrm{B}$.

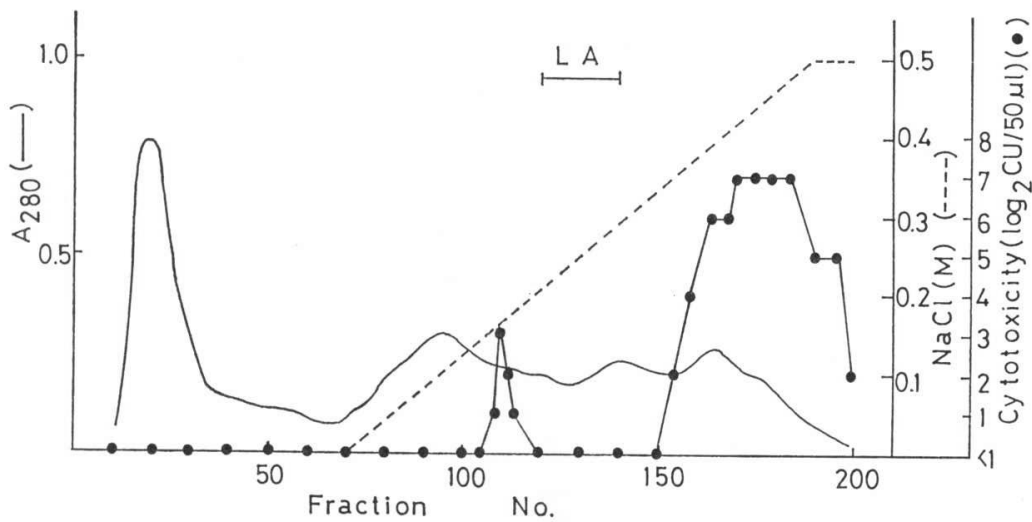

Fig. 5. DEAE-Sephacel anion-exchange chromatography profile of toxigenic strain (KZ 616) of $C$. diffcile. - cytotoxicity; -, $\mathrm{A}_{280} ;---$, Molar concentration of $\mathrm{NaCl}$; LA, latex agglutination-positive fractions.

As it is possible to detect pg level of toxin B by the cytotoxicity assay, this test is considered to be a 'gold standard' for detection of the toxins. As another detection method for $C$. difficile toxins, enzyme-linked immunosorbent assay (ELISA) was developed and has been recently clinically available $(12,54)$. Reversed passive latex agglutination test kit (CD check -D-1 kit) of Mitsubishi Chemical Industries, Tokyo, Japan, was developed as a rapid screening test for toxin A (D-1 toxin) $(1,45)$. It was reported that not only toxigenic $C$. difficile strains but also nontoxigenic strains gave positive reaction in the latex agglutination test (35). In addition, other microorganisms of $C$. sporogenes, proteolytic C. botulinum, Bacteroides asaccharolyticus, Peptostreptococcus anaerobius, showed positive reaction in the test $(4,35,57)$, indicating nonspecific cross-reaction of the latex test kit. We have checked latex agglutination (LA) activity and cytotoxicity with all fractions after anion-exchange chromatog- 
raphy using DEAE-Sephacel of $C$. difficile culture filtrates (Fig. 5). The LApositive activity was detected in the fractions between toxins $A$ and $B$, indicating that LA-positive antigen is not toxin A. The nonspecific reaction in the LA test has been also reported by Lyerly and Wilkins (55) and Borriello et al (4). Recently, it was shown that the reactive antigen in the LA test is glutamate dehydrogenase produced by $C$. difficile (51). According to the data on base sequences of the toxin genes $(13,84)$, PCR (polymerase chain reaction) method using two primers synthesized has been developed for rapid test of $C$. difficile toxins $(41,84)$. As it was reported that there was an inhibitor for PCR in the fecal extract, clinical application of the PCR method has not been performed.

\section{THERAPY FOR C. DIFFICILE INFECTION}

Therapy for $C$. difficile-induced PMC or AAD is listed in Table 9. The first step for the therapy is to suspect $C$. difficile infection and stop the administration of the causative antimicrobial agent. Next, administration of either vancomycin $(0.5-2.0 \mathrm{~g} /$ day $)$ or metronidazole $(1.0-1.5 \mathrm{~g} /$ day), effective drugs to $C$. difficile, is recommended $(17,78)$. Cholestyramine to bind $C$. difficile toxins has also been used, especially in difficult cases. Bacteriotherapy using either complex undefined combinations of fecal flora in the form of a fecal enema $(7,15)$ or a nontoxigenic avirulent strain of $C$. difficile (74) was employed for the therapy of PMC. Bowden et al (7) reported that 13 of 16 patients with PMC responded dramatically following administration of fecal enema. A different approach using nontoxigenic $C$. difficile strains by Seal et al (74) gave a successful effect to treat a case of relapse and to prevent further relapse in another patient.

Corthier et al (8) reported that prior administration of Saccharomyces boulardii decreased mortality of the gnotobiotic mouse monoassociated with $C$. difficile. It was shown that this inhibitory effect was induced by viable yeast but not by heated or irradiated yeast, and that higher doses, at least $1.0 \times 10^{9}$ cells, were needed for the protection in the mice from lethal ileocecitis by $C$. difficile (16). Recently, the sequencing of an internal fragment of the toxin A gene revealed the presence of repeat nucleotide sequences, consisting of nearly a third of the gene (8133 base pairs) at the $3^{\prime}$ end $(13,84)$. Lyerly et al $(52)$ examined the effect of vaccination

Table 9. Therapy for antimicrobial agent-associated pseudomembranous colitis or diarrhea by Clostridium difficile $(7,15,17,59,74,78)$

1. Stop administration of the antimicrobial agent responsible for the colitis or diarrhea

2. Administration of effective antimicrobial agent Vancomycin (0.5-2.0 g/day) $1-2 \mathrm{wk}$ Metronidazole (1.0-1.5 g/day) $1-2 \mathrm{wk}$

3. Binding substance to $C$. difficile toxins: cholestyramine

4. Bacteriotherapy/bacterioprophylaxis Fecal enema Nontoxigenic $C$. difficile strain 
with a nontoxic recombinant peptide comprising 33 of the 38 repeating units of toxin A gene on protection of ileocecitis in hamster by $C$. difficile. It was noted that the antiserum against the recombinant peptide neutralized the enterotoxic and cytotoxic activity of the toxin and that hamsters vaccinated with the peptide were partially protected (4 out of 8 hamsters vaccinated) against $C$. difficile ileocecitis. The two latter methods are not now applied as a clinical therapy, but it is possible that they will be new effective therapeutic method for $C$. difficile diseases.

\section{CONCLUDING REMARKS}

Willis (82) stated that "Among all the many advances that have been made in our understanding of anaerobic bacteria and anaerobic bacterial disease during the last 40 years, elucidation of the syndrome of antibiotic-associated pseudomembranous colitis ranks as a major triumph". However, the mechanism by which $C$. difficile colitis occurrs has not been fully understood. C. difficile spores can survive for longer period under an aerobic condition. Many cases of PMC and AAD have been reported to be induced by nosocomial transmission (85). Outbreaks of diarrhea due to this organism have been documented in a number of settings including cancer wards, chronic care facilities and post surgical wards. It is stated that $C$. difficile is an important nosocomial pathogen for the 1990s (85). Further analysis on both virulence factors of $C$. difficile and the mechanism of the occurrence of PMC or AAD remains to be done.

\section{REFERENCES}

(1) Banno, Y., T. Kobayashi, H. Kono, K. Watanabe, K. Ueno, and Y. Nozawa. 1984. Biochemical characterization and biologic actions of two toxins (D-1 and D-2) of Clostridium difficile. Rev. Infect. Dis. 6: S11-S20.

(2) Barroso, L.A., S.-Z. Wang, C.J. Phelps, J.L. Jhonson, and T.D. Wilkins. 1990. Nucleotide sequence of Clostridium difficile toxin B gene. Nucleic Acids Res. 18: 4004.

(3) Bartlett, J.G., T-W. Chang, M. Gurwith, S.L. Gorbach, and A.B. Onderdonk. 1978. Antibioticassociated pseudo-membranous colitis due to toxin-producing clostridia. N. Engl. J. Med. 298: 531-534.

(4) Borriello, S.P., F.E. Barclay, P.J. Reed, A.R. Welch, J.D. Brown, and D.W. Burdon. 1987. Analysis of latex agglutination test for Clostridium difficile toxin $\mathrm{A}$ (D-1) and differentiation between $C$. difficile toxins $\mathrm{A}$ and $\mathrm{B}$ and latex reactive protein. J. Clin. Pathol. 40: 573-580.

(5) Borriello, S.P., A.R. Welch, F.E. Barclay, and H.A. Davies. 1988. Detection of fimbriae amongst of Clostridium difficile. FEMS Microbiol. Lett. 49: 65-67.

(6) Borriello, S.P., A.R. Welch, F.E. Barclay, and H.A. Davies. 1988. Mucosal association by Clostridium difficile in the hamster gastrointestinal tract. J. Med. Microbiol. 25: 191-196.

(7) Bowden, T.A., A.R. Mansberger, and L.E. Lykins. 1981. Pseudomembranous enterocolitis: mechanism of restoring floral homeostasis. Am. Surg. 47: 178-183.

(8) Corthier, R., F. Dubos, and R. Ducluzeau. 1986. Prevention of Clostridium difficile induced mortality in gnotobiotic mice by Saccharomyces boulardii. Can. J. Microbiol. 32: 894-896.

(9) Dailey, D.C., A. Kasper, and R.H. Schloemer. 1987. Factors influencing the phagocytosis of Clostridium difficile by human polymorphonuclear leukocytes. Infect. Immun. 55: 1541-1546.

(10) Däubener, W., E. Leiser, C. von Eichel-Streiber, and U. Hadding. 1988. Clostridium difficile toxins $\mathrm{A}$ and $\mathrm{B}$ inhibit human immune response in vitro. Infect. Immun. 56: 1107-1112. 
(11) Davies, H.A., and S.P. Borriello. 1990. Detection of capsule in strains of Clostridium difficile. Microb. Pathog. 9: 141-146.

(12) DeGirolami, P.C., P.A. Hanff, K. Eichelberger, L. Longhi, H. Terresa, J. Pratt, A. Cheng, J.M. Letourneau, and G.M. Thorne. 1992. Multicenter evaluation of a new enzyme immunoassay for detection of Clostridium difficile enterotoxin A. J. Clin. Microbiol. 30: 1085-1088.

(13) Dove, C.H., S.-Z. Wang, S.B. Price, C.J. Phelps, D.M. Lyerly, T.D. Wilkins, and J.L. Johnson. 1990. Molecular characterization of the Clostridium difficile toxin A gene. Infect. Immun. 58: $480-488$.

(14) Eichel-Streiber, C.V., U. Harperath, D. Bosse, and U. Hadding. 1987. Purification of two high molecular weight toxins of Clostridium difficile which are antigenically related. Microb. Pathog. 2: 307-318.

(15) Eiseman, B., W. Silem, W.S. Bascomb, and A.J. Kanvor. 1958. Fecal enema as an adjunct in the treatment of pseudomembranous enterocolitis. Surgery 44: 854-858.

(16) Elmer, G.W., and G. Corthier. 1991. Modulation of Clostridium difficile induced mortality as a function of the dose and the viability of the Saccharomyces boulardii used as a preventative agent in gnotobiotic mice. Can. J. Microbiol. 37: 315-317.

(17) Fekety, R., J. Silva, C. Kauffman, B. Buggy, and H.G. Deery. 1989. Treatment of antibioticassociated Clostridium difficile colitis with oral vancomycin: comparison of two dosage regimens. Am. J. Med. 86: 15-19.

(18) Fekety, R., J. Silva, R. Toshniwal, M. Allo, J. Armstrong, R. Browne, J. Ebright, and G. Rifkin. 1979. Antibiotic-associated colitis: effects of antibiotics on $C$. difficile and the disease in hamsters. Rev. Infect. Dis. 1 : 386-397.

(19) Finney, J.M.T. 1893. Gastroenterostomy for cicatrizing ulcer of the pylorus. Bull. Johns Hopkins Hosp. 4: 53-55.

(20) Fiorentini, C., and M. Thelestam. 1991. Clostridium difficile toxin A and its effects on cells. Toxicon 29: 543-567.

(21) Galili, U., S.B. Shohet, E. Kobrin, C.L.M. Stults, and B.A. Macher. 1988. Man, apes and old world monkeys differ from other mammals in the expression of $\alpha$-galactosyl epitopes on nucleated cells. J. Biol. Chem. 263: 17755-17762.

(22) George, R.H., M. Johnson, D. Youngs, and D.W. Burdon. 1979. Induction of Clostridium difficile toxin by antibiotics, p. 955-956. In J.D. Nelson and C. Grassi (eds.), Current chemotherapy and infectious diseases, vol. 2, Am. Soc. Microbiol., Washington.

(23) George, R.H., J.M. Symonds, F. Dimock, J.D. Brown, Y. Arabi, N. Shinagawa, M.R.B. Keighley, J. Alexander-Williams, and D.W. Burdon. 1978. Identification of Clostridium difficile as a cause of pseudomembranous colitis. Br. Med. J. 1: 695.

(24) George, W.L. 1988. Antimicrobial agent-associated diarrhea in adult humans, p. 31-44. In R.D. Rolfe and S.M. Finegold (eds.), Clostridium difficile: its role in intestinal disease. Academic Press, New York.

(25) George, W.L., R.D. Rolfe, and S.M. Finegold. 1982. Clostridium difficile and its cytotoxin in feces of patients with antimicrobial agent-associated diarrhea and miscellaneous conditions. J. Clin. Microbiol. 15: 1049-1053.

(26) George, W.L., V.L. Sutter, D. Citron, and S.M. Finegold. 1979. Selective and differential medium for isolation of Clostridium difficile. J. Clin. Microbiol. 9: 214-219.

(27) George, W.L., V.L. Sutter, and S.M. Finegold. 1978. Toxigenicity and antimicrobial susceptibility of Clostridium difficile, a cause of antimicrobial agent-associated colitis. Curr. Microbiol. 1: 55-58.

(28) Giuliano, M., F. Piemonte, and P.M. Gianfrilli. 1988. Production of an enterotoxin different from toxin A by Clostridium difficile. FEMS Microbiol. Lett. 50: 191-194.

(29) Hall, I.C., and E. O'Toole. 1935. Intestinal flora in newborn infants with a description of a new pathogenic anaerobe, Bacillus difficilis. Am. J. Dis. Child. 49: 390-402.

(30) Hecht, G., C. Pothoulakis, J.T. LaMont, and J. Madare. 1988. Clostridium difficile toxin A perturbs cytoskeletal structure and tight junction permeability of cultured human intestinal epithelial monolayers. J. Clin. Invest. 82: 1516-1524. 
(31) Honda, T., I. Hernadez, T. Katoh, and T. Miwatani. 1983. Stimulation of enterotoxin production of Clostridium difficile by antibiotics. Lancet i: 655 .

(32) Ionesco, H. 1978. Initiation de la germination des spores de Clostridium difficile par le lysozyme. C. R. Acad. Sci. [D] 287: 659-661.

(33) Kamiya, S., and S.P. Borriello. 1992. A non-haemagglutinating form of Clostridium difficile toxin A. J. Med. Microbiol. 36: 190-197.

(34) Kamiya, S., X.Q. Meng, S. Nakamura, and S.P. Borriello. 1990. Detection of variant toxin A without haemagglutinating activity of Clostridium difficile, and analysis of its biochemical and biological characteristics. Jpn. J. Med. Sci. Biol. 43: 246-247.

(35) Kamiya, S., S. Nakamura, K. Yamakawa, and S. Nishida. 1986. Evaluation of commercially available latex immunoagglutination test kit for detection of Clostridium difficile D-1 toxin. Microbiol. Immunol. 30: 177-181.

(36) Kamiya, S., H. Ogura, X.Q. Meng, and S. Nakamura. 1992. Correlation between cytotoxin production and sporulation in Clostridium difficile. J. Med. Microbiol. 37: 206-210.

(37) Kamiya, S., P.J. Reed, and S.P. Borriello. 1989. Purification and characterisation of Clostridium difficile toxin A by bovine thyroglobulin affinity chromatography and dissociation in denaturing conditions with or without reduction. J. Med. Microbiol. 30: 69-77.

(38) Kamiya, S., K. Yamakawa, X.Q. Meng, H. Ogura, and S. Nakamura. 1991. Production of monoclonal antibody to Clostridium difficile toxin A which neutralises enterotoxicity but not haemagglutination activity. FEMS Microbiol. Lett. 81 : 311-315.

(39) Kamiya, S., K. Yamakawa, H. Ogura, and S. Nakamura. 1987. Effect of various sodium taurocholate preparations on the recovery of Clostridium difficile spores. Microbiol. Immunol. 31 : 1117-1120.

(40) Kamiya, S., K. Yamakawa, H. Ogura, and S. Nakamura. 1989. Recovery of spores of Clostridium difficile altered by heat or alkali. J. Med. Microbiol. 28: 217-221.

(41) Kato, N., C.-Y. Ou, H. Kato, S.L. Bartley, V.K. Brown, V.R. Dowel, Jr., and K. Ueno. 1991. Identification of toxigenic Clostridium difficile by the polymerase chain reaction. J. Clin. Microbiol. 29: 33-37.

(42) Ketley, J.M., S.C. Haslam, T.J. Mitchell, J. Stephen, D.C.A. Candy, and D.W. Burdon. 1984. Production and release of toxins A and B by Clostridium difficile. J. Med. Microbiol. 18: 385-391.

(43) Ketley, J.M., T.J. Mitchell, S.C. Haslam, J. Stephen, D.C.A. Candy, and D.W. Burdon. 1986. Sporogenesis and toxin A production by Clostridium difficile. J. Med. Microbiol. 22: 33-38.

(44) Kim, K.-H., R. Fekety, D.H. Batts, D. Brown, M. Cudmore, J. Silva, and D. Waters. 1981. Isolation of Clostridium difficile from the environment and contacts of patients with antibioticassociated colitis. J. Infect. Dis. 143: 42-50.

(45) Kobayashi, T., H. Kono, M. Aoki, K. Watanabe, and K. Ueno. 1986. Diagnosis of antimicrobial associated diarrhea by Latex immuno reagent. Proceedings of the 13th Meeting of the Jpn. Assoc. Anaerob. Infect. Res. 13: 83-88 (in Japanese).

(46) Krivan, H.C., G.F. Clark, D.F. Smith, and T.D. Wilkins. 1986. Cell surface binding site for Clostridium difficile enterotoxin: evidence for a glycoconjugate containing the sequence Gal $\alpha 1$ 3Gal $\beta 1-4 G l c N A c$. Infect. Immun. 53: 573-581.

(47) Krivan, H.C., and T.D. Wilkins. 1987. Purification of Clostridium difficile toxin A by affinity chromatography on immobilized thyroglobulin. Infect. Immun. 55: 1873-1877.

(48) Larson, H.E., J.V. Parry, A.B. Price, P.R. Davies, J. Dolby, and D.A.J. Tyrrell. 1977. Undescribed toxin in pseudomembranous colitis. Br. Med. J. 1: 1246-1248.

(49) Larson, H.E., A.B. Price, P. Honour, and S.P. Borriello. 1978. Clostridium difficile and the aetiology of pseudomembranous colitis. Lancet i: 1063-1066.

(50) Lönnroth, I., and S. Lange. 1983. Toxin A of Clostridium difficile: production, purification and effect in mouse intestine. APMIS (B) 91 : 395-400.

(51) Lyerly, D.M., L.A. Barroso, and T.D. Wilkins. 1991. Identification of the latex test-reactive protein of Clostridium difficile as glutamate dehydrogenase. J. Clin. Microbiol. 29: 2639-2642.

(52) Lyerly, D.M., J.L. Johnson, S.M. Frey, and T.D. Wilkins. 1990. Vaccination against lethal 
Clostridium difficile enterocolitis with a nontoxic recombinant peptide of toxin A. Curr. Microbiol. 21 : 29-32.

(53) Lyerly, D.M., C.J. Phelps, J. Toth, and T.D. Wilkins. 1986. Characterization of toxins A and B of Clostridium difficile with monoclonal antibodies. Infect. Immun. 54: 70-76.

(54) Lyerly, D.M., N.M. Sullivan, and T.D. Wilkins. 1983. Enzyme-linked immunosorbent assay for Clostridium difficile toxin A. J. Clin. Microbiol. 17: 72-78.

(55) Lyerly, D.M., and T.D. Wilkins. 1986. Commercial latex test for Clostridium difficile toxin A does not detect toxin A. J. Clin. Microbiol. 23: 622-623.

(56) Malorni, W., S. Paradisi, M.L. Dupuis, C. Fiorentini, and C. Ramoni. 1991. Enhancement of cell-mediated cytotoxicity by Clostridium difficile toxin A: an in vitro study. Toxicon 29: 417-428.

(57) Miles, B.L., J.A. Siders, and S.D. Allen. 1988. Evaluation of a commercial latex test for Clostridium difficile for reactivitv with Clostridium difficile and cross-reactions with other bacteria. J. Clin. Microbiol. 26: 2452-2455.

(58) Miller, P.D., C. Pothoulakis, T.R. Baeker, J.T. LaMont, and T.L. Rothstein. 1990. Macrophage-dependent stimulation of T-cell-depleted spleen cells by Clostridium difficile toxin $\mathrm{A}$ and calcium ionophore. Cell. Immunol. 126: 153-163.

(59) Nakamura, S. 1990. Virulence factors of Clostridium difficile, p. 56-97. In T. Miwatani (ed.), Igaku Saikingaku, vol. 5, Saikon Shuppan, Tokyo (in Japanese).

(60) Nakamura, S., and S. Kamiya. 1992. Rapid tests for Clostridium difficile toxins. Rinsho Kensa 36: 486-490 (in Japanese).

(61) Nakamura, S., M. Mikawa, S. Nakashio, M. Takabatake, I. Okado, K. Yamakawa, T. Serikawa, S. Okumura, and S. Nishida. 1981. Isolation of Clostridium difficile from the feces and antibody in sera of young and elderly adults. Microbiol. Immunol. 25: 345-351.

(62) Nakamura, S., M. Mikawa, N. Tanabe, K. Yamakawa, and S. Nishida. 1982. Effect of clindamycin on cytotoxin production by Clostridium difficile. Microbiol. Immunol. 26: 985-992.

(63) Nakamura, S., S. Nakashio, T. Inamatsu, N. Tanabe, N. Taniguchi, and S. Nishida. 1980. Toxigenicity of Clostridium difficile isolates from patients and healthy adults. Microbiol. Immunol. 24: 995-997.

(64) Nakamura, S., S. Nakashio, M. Mikawa, S. Okumura, and S. Nishida. 1982. Antimicrobial susceptibility of Clostridium difficile from different sources. Microbiol. Immunol. 26: 25-30.

(65) Nakamura, S., T. Serikawa, M. Mikawa, S. Nakashio, K. Yamakawa, and S. Nishida. 1981. Agglutination, toxigenicity and sorbitol fermentation of Clostridium difficile. Microbiol. Immunol. 25: 863-870.

(66) Nakamura, S., K. Yamakawa, J. Izumi, S. Nakashio, and S. Nishida. 1985. Germinability and heat resistance of spores of Clostridium difficile strains. Microbiol. Immunol. 29: 113-118.

(67) Nakamura, S., K. Yamakawa, S. Nakashio, S. Kamiya, and S. Nishida. 1987. Correlation between susceptibility to chloramphenicol, tetracycline and clindamycin, and serogroups of Clostridium difficile. Med. Microbiol. Immunol. 176: 79-82.

(68) Onderdonk, A.B., B.R. Lowe, and J.G. Bartlett. 1981. Effect of environmental stress on Clostridium difficile toxin levels during continuous cultivation. Appl. Environ. Microbiol. 38: 637-641.

(69) Pothoulakis, C., L.M. Barone, R. Ely, B. Faris, M.E. Clark, C. Franzblau, and J.T. LaMont. 1986. Purification and properties of Clostridium difficile toxin B. J. Biol. Chem. 261: 1316-1321.

(70) Pothoulakis, C., R. Sullivan, D.A. Melnick, G. Triadafilopoulos, A.A. Gadenne, T. Meshulam, and J.T. LaMont. 1988. Clostridium difficile toxin A stimulates intracellular calcium release and chemotactic response in human granulocytes. J. Clin. Invest. 81 : 1741-1745.

(71) Prévot, A.R. 1938. Etúdes de systématique bactérienne. IV. Critique de la conception actuelle du genre Clostridium. Ann. Inst. Pasteur (Paris) 61 : 72-91.

(72) Rolfe, R.D. 1991. Binding kinetics of Clostridium difficile toxins A and B to intestinal brush border membranes from infant and adult hamsters. Infect. Immun. 59: 1223-1230.

(73) Rothman, S.W., M.K. Gentry, J.E. Brown, D.A. Foret, M.J. Stone, and M.P. Strickler. 1988. Immunochemical and structural similarities in toxin $\mathrm{A}$ and toxin $\mathrm{B}$ of Clostridium difficile shown by binding to monoclonal antibodies. Toxicon 26 : 583-597.

(74) Seal, D.V., S.P. Borriello, F. Barclay, A. Welch, M. Piper, and M. Bonnycastle. 1987. Treatment 
of relapsing Clostridium difficile diarrhoea by administration of a non-toxigenic strain. Eur. J. Clin. Microbiol. 6: 51-53.

(75) Seddon, S.V., I. Hemingway, and S.P. Borriello. 1990. Hydrolytic enzyme production by Clostridium difficile and its relationship to toxin production and virulence in the hamster model. J. Med. Microbiol. 31 : 169-174.

(76) Strelau, E., B. Wagner, W. Wagner, and W. Karsch. 1989. Demonstration of capsules in Clostridium difficile. Zentralbl. Bakteriol. Hyg. A. 270: 456-461.

(77) Sullivan, N.M., S. Pellett, and T.D. Wilkins. 1982. Purification and characterization of toxins $\mathrm{A}$ and $\mathrm{B}$ of Clostridium difficile. Infect. Immun. 35: 1032-1040.

(78) Teasley, D.G., D.N. Gerding, M.M. Olson, L.R. Peterson, R.L. Gebhard, M.J. Schwartz, and J.T. Lee, Jr. 1983. Prospective randomised trial of metronidazole versus vancomycin for Clostridium difficile-associated diarrhoea and colitis. Lancet ii : 1043-1046.

(79) Thelestam, M., and I. Florin. 1984. Cytopathogenic action of Clostridium difficile toxins. J. Toxicol. Toxin Rev. 3: 139-180.

(80) Tucker, K.D., and T.D. Wilkins. 1991. Toxin A of Clostridium difficile binds to the human carbohydrate antigens I, X, and Y. Infect. Immun. 59: 73-78.

(81) Viscidi, R., S. Willey, and J.G. Bartlett. 1981. Isolation rates and toxigenic potential of Clostridium difficile isolates from various patient populations. Gastroenterology 81 : 5-9.

(82) Willis, A.T. 1988. Historical aspects, p. 15. In R.D. Rolfe and S.M. Finegold (eds.), Clostridium difficile: its role in intestinal disease, Academic Press, San Diego.

(83) Wilson, K.H., M.J. Kennedy, and F.R. Fekety. 1982. Use of sodium taurocholate to enhance spore recovery on a medium selective for Clostridium difficile. J. Clin. Microbiol. 15: 443-446.

(84) Wren, B.W., C.L. Clayton, and S. Tabaqchali. 1990. Nucleotide sequence of Clostridium difficile toxin A gene fragment and detection of toxigenic strains by polymerase chain reaction. FEMS Microbiol. Lett. 70: 1-6.

(85) Zaleznik, D.F. 1991. Clostridium difficile: an important nosocomial pathogen for the 1990s. Clin. Microbiol. Newsl. 13: 145-149. 